\title{
New Media in Internal Communications
}

Örgüt İletişiminde Yeni Medya

\section{Dr. Serap Can $^{1}$}

Başvuru Tarihi: 22.07.2019

Kabul Tarihi: 18.09.2019

\begin{abstract}
Communication is a cyclic process that involves collecting and exchanging of the information within the boundaries of dialogue and mutual understanding. As a rapidly growing field in communication studies; internal communication is vital for organizations to build healthy and sustainable relationships with their publics. Ideal internal communication applies to two-way exchange of knowledge with a proper feedback and helps establishing a democratic, productive and fair environment within the organization.
\end{abstract}

Long, technology converts both the world and the people in the way of living. As a communicative revolution; new media has everlastingly transformed the way the individuals build relationships. These novelties naturally apply to the internal communications of the organizations. Providing necessary information to the publics, it is better for the organizations to benefit from new media in internal communication processes so as to be an open system.

As the use of new media uptrends, the organizations have to transform themselves. At this point; new media and its numerous applications become prominent to reach the success for the organizations. In this article; it is aimed to evaluate and examine the internal communication phenomenon with the recent applications of new media in the organizational processes.

Keywords: Internal Communication, Organization, Dialogue, Social Media, New Media

Öz

İletişim, anlayış ve diyalog çerçevesinde bilginin toplanması ve değişimini içeren döngüsel bir süreçtir. İletişim çalışmaları kapsamında en hızlı gelişen alanlardan birisi olan örgüt iletişimi, örgütlerin iç ve dış paydaşları ile sağlıklı ve sürdürülebilir ilişkiler kurabilmesi için hayati önem taşımaktadır. İdeal bir örgütsel iletişim; demokratik, verimli ve adil bir ortamın oluşturulabilmesi için gereken bilginin iki yönlü alışverişini ve geri bildirimi sağlamaktadır.

\footnotetext{
${ }^{1}$ Gazi University, serap@gazi.edu.tr, ORCID: 0000-0003-3779-6172
} 
Uzun zamandır, teknoloji hem dünyayı hem de bireylerin yaşam biçimini pek çok farklı şekilde dönüştürmektedir. İletişimsel bir devrim olarak yeni medya; bireylerin diğer diğerleri ile olan ilişkilerini ebediyen değiştirmiştir. Bu değişiklikler elbette örgütlerin iletişim biçimlerine de yansımaktadır. Paydaşlara gereken bilgileri sağlamak üzere; örgütler için iletişim süreçlerinde yeni medyadan faydalanmak ve açı sistemler haline gelmek son derece önemlidir.. Dolayısıyla her türden örgüt için açık bir sistem haline gelmek, iletişim kanallarının düzgün ve düzenli çalı̧ması ile yaşam şansını arttıran bir özellik haline gelmiştir.

Toplumda yeni medyanın kullanımının artmasıyla, örgütler de operasyonların ve süreçlerini teknolojik ve toplumsal değişimlere göre düzenlemek durumundadır. Bu noktada, yeni medya ve bu platformda yer alan sayısız uygulama, örgütlerin yaşam döngülerinde başarıya ulaşması için öne çıkan etmenler olmaktadır. Bu çalş̧̧ada; örgütsel iletişim olgusunun özellikleri, unsurlar ve faydaları değerlendirilerek örgütlerin iç iletişim süreçlerinde kullamılan çeşitli yeni medya uygulamaları incelenmektedir.

Anahtar Kelimeler: Örgüt İletişimi, Örgüt, Diyalog, Yeni Medya, Sosyal Medya

\section{Introduction}

As a social being, one of the most important elements of human existence is communication. The only characteristic makes human a real human and keep people together is that they can communicate. The more the accuracy and quality of the communication increases, the more the quality of life increases. This works for the organizations too, the efficiency and continuity of an organization depends on the quality of the communication processes formed and sustained both internally and externally.

Being the structures that maintain their lives on specific targets and rules, the organizations borrow human and information resources from the society and offer goods, products and services in return. The communication processes of the organizations enable the continuousness of healthy and open relationships with both staff and stakeholders. Today, these processes are carried out with new media tools as well as traditional communication channels. The implementation of the elements of new media to the internal communication processes undoubtedly prepossesses the organizational culture and personal satisfaction.

This study aims to examine the features of internal communication and new media tools implemented in internal communication processes.

\section{Communication and Dialogue}

Communication, originating from the Latin word "communicare", basically means partnering and sharing. In ancient times, the sharing was on food and hunt but nowadays it transformed into the sharing of information. With the development of technology, both the form and the content of communication change. Simply; communication is the process of production, 
transfer and interpretation of the information. It is a meaning transfer process that plays an important role in social interactions right after the individuals started living together.

Within the social sciences, communication is branched due to how and with whom it appears. Internal communication is one of those branches that has formal rules, borders and hierarchy that occurs human groups that the members come together for specific duties and responsibilities.

Internal communication is based on people and responsibilities in different kinds of organizations; so, it is best maintained with the help of dialogue. In communication studies, the notion of dialogue expresses the establishment of communication between the individuals and/or organizations and their target audiences. One of the first to use the concept of dialogue in communication studies is Pearson with his dissertation in 1989. He stated that forming and maintaining communicative relations with all target audiences is morally true and naturally, it is incorrect not to do this" (Kent and Taylor, 2002, s.21). The point is, dialogue should be constructed and sustained in a mutual and two-way structure in equal parts. Namely, dialogue is a continuous process instead of an ultimate result. Dialogue corresponds to enhance understanding, sharing and interpreting the meanings as well as increase learning and collaboration.

Dialogue, of which ultimate aim is not persuasion, change or discussion, but aims to develop relationships, is a concept based on the principle of being aware of the other. Providing a comfort zone for freedom of thought and speech; dialogue allows organizations build an organic link not only with their audiences but also its members. Besides all its advantages, dialogue requires organizations to be socially responsible and enables them to contribute to both their environment and society to reach the better (Kent, 2017, s.3).

\section{Characteristics of the Organizations}

The association that emerges from the needs of collaboration between individuals and the division of labor is called an organization. There must be a purpose for individuals to form an organization. As an open system; an organization is composed of common purposes and individuals that are enthusiastic about communicating and reaching those purposes. An open system means that the organization is always in communication with its environment. Open systems are sensitively reactive to the changes occurred within their environment and also they can easily adjust and adapt those changes through mutual communication and understanding. Subsuming many different sub-systems, the organizations are the organisms that consist of different hierarchical activities and responsibilities of individuals that came together to realize the specific goals in a collective, effective and sufficient way. Organizations and its members can be successful to the extent that they understand and internalize the goals and objectives of the organization. To reach this point; an open, clear and sustainable dialog and communication process should be established throughout the organization.

\section{Internal Communications in Organizations}

In today's world; digital and technological developments are quite rapid and difficult to capture for both individuals and organizations. In a complex and competitive business environment 
with those technological developments; it is compulsory for the organizations to catch up and keep their publics together both internally and externally (Reitz, 2012, s.44).

As a basic component of organization management; communication helps the members understand their roles, duties and responsibilities within the structure. Mobility of the information throughout the organization also positively contributes the loyalty, satisfaction and motivation of the members as well as the wellness of the processes.

The aims of the internal communication are as follows (Güllüoğlu, 2011, s.24-25; Tutar, 2009, s.162);

- Announcement of organizational policies and decisions, preventing the vagueness and rumors.

- Clearly informing the members about working conditions, financial matters, budget, carrot and sticks, career options, projects, activities and more in order to ensure the organizational loyalty and trust.

- Via the continuous information flow; developing the organizational integrity and solidarity by establishing a family-like environment with friendship, commitment and respect.

- Helping the members to learn and internalize the organizational culture.

- Briefing the members to understand their duties, authorities and responsibilities.

- Maintaining the control all across the organization in order to solve the possible problems in a proactive way.

- Coordination between the members, groups and departments align with the management.

- Establishing and maintaining both internal and external communication processes with the organization's target audiences and publics.

With the help of internal communication; the organizations can yield in many respects. Top management can collect the necessary information to make decisions while the directions and instructions can be transferred to the relevant members and department. Continuous communication increases the sense of belonging and sharing while enhancing the productivity and performance. Also the oppression, mobbing and conflicts can be eliminated easily. All these positive outputs bring the profitability and success.

Different organizations prefer different communication forms according to their aims, members and environments. There are four main communication forms defined such as bureaucratic, manipulative, disproportional and democratic (Kıraç, 2012, s.40-41).

Bureaucratic communication is also known as one-way communication model. Mostly seen in public institutions as a downwards communication process. Informing the target audiences and collecting data from them are generally disregarded.

In manipulative communication, also known as press agency model; persuasion and influence are at the forefront while the receiver (or the target audience) is passive. Organization selects the advantageous and serviceable information to share with the target audiences. During the 
communication process, the negative and disadvantageous information is hidden from the others. Being sender-oriented; it is mostly used in the fields of rhetoric, propaganda and politics.

Disproportional communication is lame and interrupted way of communicating as the organization is ready to establish the necessary environment but cannot provide adequate information from its target audiences and publics.

Democratic communication, or two-way symmetrical model of communication is based on transparency and clarity. The organization is attentive to the internal and external information flow. As a two-way and contemporary model; communication processes are both downwards and upwards. Regarding dialogue, mutualism and common interests; democratic communication corresponds with the values and concepts of today's world.

Organizations regulate their communication processes through formal (official) and informal (unofficial) communication channels. Formal communication channels allow the organization to fulfill its vital functions while regulating the superior-subordinate relationships. Regular reporting, establishment of correspondence orders and rules and communication hierarchy are defined by official communication channels. Accordingly; members of an organization can communicate downwards, upwards, horizontally and diagonally. Downwards communication often flows from top management to the members (or employers). Submitting duties, authorities and responsibilities of the individuals, giving instructions and reward - punishment system occur downwards. Contrarily, upwards communication flows from the members to the management level. Daily, weekly, monthly or annual reports, assistance requests, wishes and complaints are transferred upwards. Horizontal channels provide communication between colleagues and organizationally equal members. Diagonal communication is used for sustaining communication between individuals, groups and departments with different levels. Especially in crisis periods; diagonal communication is vital to take action or make decisions quickly. On the other hand; communicating diagonally in normal periods may damage organizational hierarchical structure and cause problems.

Informal channels are self-induced ways of communications within the organizations. Those natural relationships are of great importance in increasing the commitment and satisfaction of the individuals. Not bound by any rules and include sincerity; informal communication is an easy way to keep in touch with the members, by the way, it is useful to be careful as it can lead to rumors and gossip and thus unrest within the organization.

Internal communication is one of the increasingly noticeable fields of communication studies for more than two decades (Vercic et al., 2012, s.223). Its components, forms and rules are of great importance to establish and maintain a healthy internal communication process within organizations of any size and kinds. The basic contents of internal communication are providing information for the individuals, internal public relations processes and building standards, activities, consolidation and organizational culture (Hola, 2007, s.107). No matter what methods and processes are used, internal communication should be designed and carried out by experts with the help of latest innovations and contemporary technologies. 
The organizations that attach importance to communication processes have to choose appropriate channels for their aims, size, target audiences and publics. In the selection of these channels, internal, external, formal and informal communication processes should be determined and communication activities should be planned accordingly. Many organizations use traditional communication tools, but today's evolving technology now allows everyone to access the flow of information anytime and anywhere. Therefore, in order to stay up to date, make and apply quick decisions and be effective especially in crisis periods, it is of great importance to use new media in addition to traditional media.

\section{New Media in Internal Communications}

1.1Traditional internal communication channels include telephone, letter, fax, brochures and catalogues. Today, electronic (digital) solutions are used both for the rapid circulation of information and for the safe storage of content and data. Digital channels also protect organizations from loss of time and content, storage costs with large folders and shelves, and security measures to prevent leakage or loss of information. As a part of this digital era; the new media offers many advantages to the organizations and its members. New media, social media or digital applications transformed daily communication forms by providing easy platforms for the individuals and organizations to interact with each other in a dynamic and proper dialogue (Reitz, 2012, s.43). Encouraging the dialogue in internal communication processes via new media technologies is vital because the organizations can adapt and modify themselves to novelties with the help of two-way symmetrical communication that those technologies provide (Kent and Taylor, 1998, s.326).

1.2The new media, which allows for two-way, symmetrical and dialogue-based communication, is the name given to all Internet-based applications built on the ideological and technological foundations of Web 2.0 that let users create and share content (Kaplan and Haenlein, 2010, s.61).

New media, also known as social or digital media; has a significant impact on our daily lives. With a content and user-oriented structure; new media is the formation of a very common and comprehensive communication tool with blogs, microblogs, photo and visual sharing sites, social networking sites, music sharing sites, forums, advice and complaint sites, podcasts and so on.

There are four main features of new media such as integration, time effectiveness, least effort and orderliness ( $\mathrm{Hu}$ and Lin, 2013, s.188). New media connect the individuals all around the world, so they can easily share information. Integration of the people and content resources show the small world phenomenon or the global village theory. Via new media, individuals can send and receive information whenever they want, there is no time limits or boundaries in this new digital world. New media is nearly open and free to every other individual around the world, this means the users (or participants) do not need any special skill or training to use the platforms of new media. This means the people make the least effort to utilize the content in the new media. Due to Web 2.0 characteristics; new media is open and dynamic. Within this 
changing environment, there is a self-organization mechanism that eliminates false and unnecessary elements from the platforms as the individuals can edit and revise the content.

Due to these features, there are important differences between new and traditional media. Traditional media is safe and stabilized but new media generally far overweigh it. New media can reach the supreme amount of individuals while the audience of the traditional media is limited. New media is open to revising, editing and even deleting the contents published but every one letter published in the traditional media cannot be deleted forever. The contents that created by the users in new media is sent worldwide as soon as the user clicked the "publish" button whereas people have to wait until the traditional tools are prepared, controlled and transported or broadcasted. So, the content of traditional media may sometimes be out of date. New media offers a two-way communication while traditional media is only one-way. This means new media enhances dialogue but traditional media cannot.

According to We Are Social 2019 global data, nearly 4.5 billion individuals worldwide use the Internet, accounting for $58 \%$ of the total world population. Moreover; more than 3.4 billion individuals actively use new media, almost all of them prefer mobile connection. Considering one-year process, Internet users worldwide increased by 8.6\% between April 2018 and April 2019 , while new media users increased by $6.1 \%$. The top five new media applications worldwide are Facebook, YouTube, WhatsApp, Facebook Messenger and WeChat.

As more and more individuals use new media, the organizations evolve their communication styles, too. Nowadays, almost every organization has a web page. The memorability of the addresses of these web pages, visual designs, being constructed in a user-friendly way that can be understood by people of all ages and socio-economic level; can be shown as the first steps of successful internet communication. Providing up-to-date, clear, complete and comprehensive information about the organization's history, mission and vision statements, activities and contacts; is the key for a website to be successful. Access to relevant persons or units via messaging application or direct e-mail from web page; is also important for a healthy communication process.

Web pages host a lot of written and audio-visual content; sometimes it is a disadvantage for today's mobile people. Connecting to a website from devices such as mobile phones and tablets; sometimes result in technical problems, the site may not work properly or the information sought cannot be found immediately. Therefore, in addition to a healthy website; the use of new media channels becomes compulsory. These new media channels mostly include Facebook, Twitter, Instagram, YouTube, LinkedIn and WhatsApp. Facebook offers page designs suitable for the use of many types of organizations such as businesses, non-governmental organizations, SMEs, entrepreneurs or educational institutions. Here; just like a web page, many of the content of the organization can be presented in a much more remarkable way, organic audience groups can be formed and organizational loyalty can be achieved through comments and testimonials. 
1.3Similarly, Twitter provides both a simple interface and the ability to write short texts up to 280 characters, enabling organizations to carry out a problem-solving and crisis managementbased process, especially in external communication with their target audience and stakeholders. Instagram; since it is a visual sharing platform, it is an important platform especially for organizations with visual contents to present. It is also possible to reach the target audience and keep the communication warm with the options of opening an individual or commercial account on Instagram. YouTube is a video sharing application. Organizations can publish videos about their products, goods and services, and upload videos about their activities such as in-house trainings and seminars. It is also possible to establish an organic connection with users through comments and subscriptions via YouTube. LinkedIn offers more features with the premium version, but is free to use like other new media tools. As a professional business network, it is more a business based social sharing platform. LinkedIn is used by users to find, change jobs or employees; it is also an appropriate medium to be informed of the sector, colleagues and the latest developments. WhatsApp is one of the most widely used free messaging applications. It is possible to establish informal but quick communication with groups created on WhatsApp. Especially in crisis periods where the importance of rapid decision-making is needed and the hierarchy is set aside, it will be a right way to take immediate action and intervene with the messaging applications.

There are several points to be considered in the use of all these new media channels. The user names, profile photos and visual designs of the selected new media platforms should be prepared in accordance with the organizational identity and culture. The user names and addresses of all these platforms should be displayed on the main website and should be directly linked. In the management of these channels, immediate feedback should be given due to the time effectiveness and least effort features of new media. In communication with the target audiences, neither a very formal nor a very informal language should be used; the balance of respect and sincerity must be observed.

As far as the organization's external communication processes; the conduction of internal communication processes through the new media also contributes both to savings in various areas and to increasing productivity. Long reports that did not fit into folders before, documents sent or received by hand or mail both lost time and energy and also caused the loss of information. Today, the communication processes created with a single click of a button have facilitated the flow of information.

In parallel with all these developments; the official and informal communication channels of the organizations have now been moved mostly to electronic platforms of new media. Organizations facilitate and streamline their workflows and internal communication processes with many different applications. These applications are usually purchased as package services. The most widely used ones are Intranet, Microsoft Office365, Google Services, ERP and EBYS.

Thanks to the Intranet or the local internet, the network that is established within the organization, the members can maintain their communication processes inside. Intranet, equipped with various security systems; provides the members the circulation of information, 
resources and content specific to the organization. Microsoft Office 365 is a platform where all Microsoft applications are aggregated. When organizations login this licensed and paid application, each member becomes a user with various privileges according to their roles. The platform includes many components such as the applications of documentation, e-mail, visual presentation, survey, calendar, task creation, planning and tracking, video sharing, joint project execution and content storage. The SharePoint application on this platform provides organizations with an internal communication network that can also be used mobile. SharePoint, which also functions as an intranet, allows its users to follow their organization's web pages, new media platforms and other members. By accessing the organizational portal; members can access a broad content such as documents, visuals, presentations and videos, announcements, people and both internal and external contact information; they can make sharing, additions, arrangements about them, participate in discussions and form groups. Through SharePoint, users can intervene online workflows within the organization. Another application in Office 365 is Yammer. This application, also known as Corporate Facebook, is similar to LinkedIn in terms of its features. Yammer, logged in with the license of the organization, also has a mobile version. Thus, users can share, form groups and stay up to date in the context of organizational communication wherever and whenever they want. Similarly, services offered by Google include document processing, photos, video sharing, video calls, email, calendar, and cloud storage free for everyone. Unlike Microsoft Office 365, these services are not available as a package, but can be used individually depending on the needs. Through these services, users can create and share documents and audiovisual content related to the organization and exchange information. In addition to being cost-effective, it is a communication channel preferred by organizations because of Google's user-friendly interfaces and ease of access. ERP (Enterprise Resource Planning) is actually an organizational resource envisioning application, but it is also used effectively in regulating the communication processes of organizations in terms of efficient management. ERP software, which allows organizations to combine all their resources and data in a single pot and use them more efficiently, is generally implemented by outsourced experts and used as a package. Mostly preferred by organizations manufacturing based on projects, ERP improves cooperation and productivity through real-time information flow by harmonizing different departments and groups. ERP software, which enables all activities and communication processes to be carried out electronically, has a wide range of applications from multinational conglomerates to SMEs. Electronic Document Management System (EBYS) is a system that is used mostly in public institutions, facilitating the management of documents and ensuring safe and regular communication internally and externally. Thanks to this system, the processes of secure sending, receiving, backing and archiving of the documents prepared within the organization is carried out electronically. Due to this system, communication and cooperation between the managers, members and publics of the organization can be monitored and regulated 7 days 24 hours according to their levels of authority. EBYS brings profitability to its users in terms of time and cost.

\section{Conclusion}

Organizations are living systems composed of members, targets, rules and hierarchy. Individuals with different roles, authorities and responsibilities perform their duties and jobs in order to reach specified targets and operations. During those operations and processes; members need continuous flow of accurate information in order to be successful.

With the help of internal communication; the transfer of decisions and news, clarification of the situations and conflicts, persuasion and influence processes, keeping up with the agenda 
and monitoring, share and exchange of information, profiting and growth are easily conducted. Moreover; internal communication provides a healthy, sincere and home-alike environment for the members and this results in enhancement in organizational loyalty, commitment and culture.

In case the internal communication is interrupted and / or messed; the members' motivation, commitment, excitement and positivity decrease. Also, the fails in coordination, competition, strategic targeting can be observed throughout the organization which will eventually end up with the disorder and collapse.

In view of such advantages and disadvantages of internal communication and due to recent developments; the most suitable way of providing information flow within the organization is the use of new media. As new media has irremediably changed the way people and organizations establish and maintain the communication processes; the organizations should adapt themselves to these new platforms and applications of new media.

There are lots of different digital solutions for organizations to regulate their internal communication processes. Either paid or free; there are a great variety of applications that provide establishment of communication channels, crisis management, building organizational loyalty and culture, management, storage and security of documentation and ensuring the environment of sincerity and respect with the notions of openness, transparency and honesty. In order to be successful; every organization should prepare an internal communication plan with proper internal communication channels suitable for their missions, visions and targets.

\section{References}

Güllüoğlu, Ö. (2011). Örgütsel İletişim-İletişim Doyumu ve Kurumsal Bağhllık, Konya: Eğitim Akademi.

Hola, J. (2007). The Importance of Internal Company Communication, Ekonomika ir vadyba: aktualijos ir perspektyvos, 1(8). 107-111.

Hu, H. and D. Lin. (2013). Feature Analysis of Social Media, IWCSS International Workshop on Computer Science in Sports, 186-190.

Kaplan, A. M. and M. Haenlein. (2010). Users of the world, unite! The challenges and opportunities of Social Media, Business Horizons, 53, 59-68.

Kent, M. L. and M. Taylor, (1998). Building Dialogic Relationships Through the World Wide Web, Public Relations Review, 24(3), 321-334.

Kıraç, E. (2012). Örgütsel İletişimin Örgütsel Bağlılık Algılaması Üzerindeki Etkileri ve Bir Araştırma (Yayımlanmamış Doktora Tezi), Pamukkale Üniversitesi Sosyal Bilimler Enstitüsü, Denizli.

Reitz, A. (2012). Social Media's Function in Organizations: A Functional Analysis Approach, Global Media Journal - Canadian, 5(2), 41-56.

Tutar, H. (2009). Örgütsel İletişim, Ankara: Seçkin.

Vercic, A. T., D. Vercic and K. Sriramesh. (2012). Internal Communication: Definition, Parameters and the Future, Public Relations Review, 38(2012), 223-230. 